\title{
Dynamics of insulin-like factor 3 and its receptor expression in boar testes
}

\author{
Itaru Minagawa, ${ }^{1,2}$, Dai Sagata', Ali Mohammed Pitia ${ }^{1,2}$, Hiroshi Kohriki, \\ Masatoshi Shibata ${ }^{3}$, Hiroshi Sasada ${ }^{4}$, Yoshihisa Hasegawa ${ }^{5}$ and Tetsuya Kohsaka ${ }^{1,2}$ \\ 'Laboratory of Animal Reproduction and Physiology, Department of Applied Biological Chemistry, \\ Faculty of Agriculture, Shizuoka University, 836 Ohya, Suruga-ku, Shizuoka 422-8529, Japan \\ ${ }^{2}$ Division of Animal Resource Production, The United Graduate School of Agricultural Science, \\ Gifu University, Gifu, Japan \\ ${ }^{3}$ Shizuoka Swine and Poultry Experimental Station, Kikugawa, Shizuoka, Japan \\ ${ }^{4}$ Laboratory of Animal Reproduction, School of Veterinary Medicine, Kitasato University, Towada, Japan \\ ${ }^{5}$ School of Veterinary Medicine, Animal Sciences High-Tech Research Center, Kitasato University, Towada, Japan
}

Correspondence should be addressed to T Kohsaka

Email

t-kohsaka@agr.shizuoka.ac.jp

\begin{abstract}
Relaxin-like factor (RLF), now mainly known as insulin-like factor 3 (INSL3), is essential for testis descent during fetal development; however, its function in the adult testis is still being elucidated. As a major step toward understanding the as-yet-unknown function of INSL3 in boars, this study aimed to develop a time-resolved fluoroimmunoassay for boar INSL3, characterize the dynamics of INSL3 expression during development, and demonstrate the expression of the INSL3 hormone-receptor system in the testis. All samples were collected from Duroc boars. The sensitivity of the assay system established was $8.2 \mathrm{pg} /$ well $(164 \mathrm{pg} / \mathrm{ml})$, and no cross-reactivity with other hormones, such as porcine relaxin, was observed. Circulating INSL3 was shown to increase progressively during development. INSL3 secreted from the Leydig cells was released not only into the blood circulation but also into the interstitial and seminiferous compartments in sufficient concentrations. A testicular fractionation study revealed that its receptor RXFP2 transcripts were expressed mainly in testicular germ cells. In addition, INSL3 bound to the germ cell membranes in a hormone-specific and saturable manner. These results reveal that INSL3 secreted into the interstitial compartment from the Leydig cells is transported into the seminiferous compartments, where its receptor RXFP2 is expressed mainly in the germ cells to which INSL3 binds, suggesting that INSL3 functions as a paracrine factor on seminiferous germ cells.
\end{abstract} Key Words

\section{Introduction}

Testicular function is regulated by the complex interplay of many different molecules that include both endocrine and paracrine signalings, and proper regulation is critical for optimum male reproductive capacity. Of these molecules, relaxin-like factor (RLF), now mainly known as insulin-like factor 3 (INSL3), is a novel member of the insulin-relaxin (RLN) gene family, which was originally discovered by screening a boar testicular cDNA library (Adham et al. 1993), and is produced by both fetal and adult Leydig cells. INSL3 binds with high affinity to and activates its specific receptor, now known as RLN family peptide receptor 2 (RXFP2; originally called LGR8, leucinerich G-protein-coupled receptor 8) (Hsu et al. 2002, Kumagai et al. 2002). INSL3 plays an essential role in testis 
descent during fetal development by acting on the gubernaculum via RXFP2, as revealed by mouse models targeting genes encoding either Insl3 (Nef \& Parada 1999, Zimmermann et al. 1999) or Rxfp2 (Gorlov et al. 2002, Bogatcheva et al. 2003).

After birth, however, the physiological role of INSL3 remains unknown, despite the fact that the INSL3 gene and its protein are highly expressed in the adult testes of a number of mammalian species (Ivell \& Bathgate 2002). Recent evidence in some species, such as humans and rodents, suggests that INSL3 might be involved in the regulation of testicular function in adult males. The development of a specific immunoassay system using a synthetic peptide consisting of an A-B heterodimer based on human and rodent cDNA sequences has revealed that circulating INSL3 levels increase progressively during pubertal development (Boockfor et al. 2001, Ferlin et al. 2006, Wikström et al. 2006, Anand-Ivell et al. 2009) with a subsequent decline by aging in males (Anand-Ivell et al. 2006b). In addition, the receptor RXFP2 in INSL3 has been detected in seminiferous germ cells (Kawamura et al. 2004, Anand-Ivell et al. 2006a, Feng et al. 2007) and Leydig cells (Anand-Ivell et al. 2006a, Feng et al. 2007). Furthermore, INSL3 was reported to suppress male germ cell apoptosis in the testes (Kawamura et al. 2004) and to stimulate the proliferation of the mouse Leydig cell line TM-3 (Feng et al. 2007), whereas another study reported no effect of INSL3 on either adult-type rat and mouse primary Leydig cells or the mouse Leydig cell tumor cell line MA-10 (Ivell \& Anand-Ivell 2009).

Exploring the function of INSL3 in boars is especially intriguing, because boars differ from other mammalian species in having species-specific characteristics in testicular morphology and function. For example, the volume percentage of Leydig cells per whole testis of mature boars is much higher (Peyrat et al. 1981) than that of other species including rodents (2-6\%) (Ewing et al. 1979, Chamindrani Mendis-Handagama 2012). Furthermore, boar testes secrete large quantities of estrogens, wherein plasma estradiol-17 $\beta\left(\mathrm{E}_{2}\right)$ levels increase in a stepwise fashion during pubertal development (Allrich et al. 1982, Schwarzenberger et al. 1993, Estienne et al. 2000). In addition, an androgen-binding protein expressed by Sertoli cells could not be identified (Jegou \& Le Gac-Jegou 1978), but testosterone concentrations in the tubular fluid are high (Claus et al. 1985). Despite accumulating data on boars, there has been very little progress in understanding the function of INSL3, even though INSL3 was first discovered in the boar testis. We recently purified native INSL3 from the boar testis and demonstrated for the first time that native INSL3 is secreted from Leydig cells as a 12 Da B-C-A single-chain form with full biological activity, suggesting that in boars, INSL3 appears to be physiologically relevant (Minagawa et al. 2012). It is quite interesting, therefore, how INSL3 production and secretion change during development, and how and where the secreted INSL3 acts in this species. In addition, identifying the cell type(s) that expresses the receptor RXFP2 and specific INSL3 binding in target cells would be a major step toward understanding the as-yet-unknown function of INSL3 in boars.

In this study, we characterized the dynamics of INSL3 expression during pubertal development in boars and demonstrated the presence of RXFP2 mRNA and specific INSL3 binding in the testis. For measurement of INSL3 concentrations in the serum and testicular body fluid, an immunoassay for INSL3 in boars using a time-resolved fluoroimmunoassay (TR-FIA) platform was developed.

\section{Materials and methods}

\section{Animals and sampling}

Animals All samples were collected from Duroc boars at the Shizuoka Swine and Poultry Experimental Station and from the local slaughterhouse. The animal experiments and procedures were all approved by Shizuoka University Animal Experimentation Ethics Committee.

Peripheral serum Sera were collected from the jugular vein of boars aged 7-15 weeks (prepuberty, $n=7$ ), 17-21 weeks (onset of puberty, $n=7$ ), 24-30 weeks (puberty, $n=15$ ), 36-38 weeks (postpuberty, $n=8$ ), and 48 weeks-3.3 years (adult, $n=13$ ), and then stored at $-80^{\circ} \mathrm{C}$.

Body fluid compartments Various body fluid compartments of the reproductive system were obtained from eight adult boars. Each right testis was cut in half vertically along the midline. To collect the rete testis fluid, a biopsy punch $6 \mathrm{~mm}$ in diameter (Kai Medical, Gifu, Japan) was pushed into the rete testis while it was frozen by using liquid nitrogen and the fluid was collected after centrifugation. To collect the seminiferous tubular fluid, testicular slices were washed to remove contaminating interstitial fluid by soaking briefly in cold $10 \mathrm{mM}$ PBS (pH 7.4) and blotting on filter paper to remove extratubular fluid. The intratubular fluid was sucked out using a fine Pasteur pipette under a stereomicroscope. To collect the efferent duct fluid, the ducts were isolated, microdissected,

Published by Bioscientifica Ltd 
and centrifuged. Epididymal fluid was collected from the lower part of each cauda epididymis as described previously (Kohsaka et al. 2001). An 18-gage blunt needle attached to a pump was inserted into the vas deferens and the epididymal fluid was collected by flushing the cauda epididymis with air. In contrast, each left testis was used to collect testicular interstitial fluid, which was taken from a small incision in the caudal end of the testicular capsule, as described by others (Hedger \& Hettiarachchi 1994). In addition, testicular venous sera were collected from the spermatic cord, while peripheral sera were taken from the jugular vein. All samples collected were centrifuged at 1500 or $6000 \mathrm{~g}$ for $10 \mathrm{~min}$ at $4{ }^{\circ} \mathrm{C}$ and stored at $-80^{\circ} \mathrm{C}$.

Testes Testes were obtained by castration or just after slaughter of 5- and 7-week-old (prepuberty, $n=3$ for each group), 18-week-old (onset of puberty, $n=3$ ), 30-week-old (puberty, $n=3$ ), 38-week-old (postpuberty, $n=3$ ), and 46-week-old (adult, $n=3$ ) boars. Each testis was cut from the parenchyma in the medial part using a razor blade. Pieces of the harvested tissues were rapidly frozen and stored in liquid nitrogen, while other specimens were fixed in Bouin's solution and embedded in paraffin for immunohistochemistry.

\section{Protein concentrations}

The protein concentrations were determined by using the Lowry-Folin method, with BSA as a standard (Hess et al. 1978).

\section{Insulin-like factor 3}

Native INSL3, which we previously purified from mature boar testes (Minagawa et al. 2012), was used for development of the TR-FIA and for the binding assay. Purified INSL3 has a $12 \mathrm{kDa}$ single-chain structure comprising three domains, B-C-A, and exhibits full bioactivity in human embryonic kidney (HEK)-293 cells expressing mouse Rxfp2. Recombinant INSL3 (recomb. INSL3) $(\sim 16 \mathrm{kDa}$, calculated mass of 15751$)$ was expressed in Escherichia coli by using a construct that expresses the His-tagged INSL3 sequence containing the B-C-A domain inserted into the pCold I vector, as described previously (Kato et al. 2010), and was used for antibody production, because there was an insufficient amount of the $12 \mathrm{kDa}$ native INSL3 for antibody production. The recomb. INSL3 was larger in molecular size than native INSL3 because it was fused with a 32-residue linker (calculated molecular weight of $3675 \mathrm{Da}$ ) derived from the vector. The linker consists of a His-tag sequence followed by a translationenhancing element sequence, and a factor Xa cleavage sequence. It probably lacks biological activity due to misfolding. In addition, a synthetic human A-B heterodimeric INSL3 peptide (6292 Da; Phoenix Pharmaceuticals, Burlingame, CA, USA) was used to demonstrate antibody specificity by western blotting.

\section{Production of antiserum for INSL3}

Rabbit polyclonal antiserum for boar INSL3 was generated by using the recomb. INSL3 according to our method (Kato et al. 2010). Briefly, recomb. INSL3 $(2 \mathrm{mg} / \mathrm{ml})$ was emulsified in an equal volume of Freund's complete adjuvant (Difco, Detroit, MI, USA) containing $2 \mathrm{mg}$ of desiccated Bacto M. Butyricum (Difco) and immunized adult female New Zealand white rabbits $(n=2)$. Booster injections consisting of the same quantity of antigen in Freund's incomplete adjuvant (Difco) were given at an interval of 2-3 weeks. Blood of sufficiently high titer was collected from an ear vein and by heart puncture, after which serum was stored at $-80^{\circ} \mathrm{C}$. The titer of the antiserum was monitored by ELISA.

\section{Development of TR-FIA for boar INSL3}

We developed a competitive TR-FIA for boar INSL3. Purified boar INSL3 was labeled using europium (Eu)labeling reagent (Perkin-Elmer, Boston, MA, USA). As Eu is known to bind to the free amino groups of proteins (Lövgren et al. 1985), it is thought to have labeled the lysine residue (Lys) that only exists in position 12 of the B-domain ( $\mathrm{Lys}^{\mathrm{B} 12}$ ). It probably also labeled the $\mathrm{N}$-terminus of native boar INSL3, comprising the B-C-A single-chain form, which is made up of 111 amino acid residues. The TR-FIA procedure was performed according to our protocol (Ogine et al. 1999). Briefly, $50 \mu \mathrm{l}$ of standard or samples was added to goat anti-rabbit immunoglobulin G (IgG) coated microplates (Perkin-Elmer) together with $100 \mu \mathrm{l}$ of anti-INSL3 antiserum (1:5000). After $1.5 \mathrm{~h}$ incubation on a plate shaker, $100 \mu \mathrm{l}$ of Eu-labeled INSL3 $(5 \mathrm{ng} / \mathrm{ml})$ was added and the plates were shaken for another $3.5 \mathrm{~h}$. Enhancement solution $(200 \mu \mathrm{l} /$ well; Perkin-Elmer $)$ was added after washing, and the fluorescence was measured using a 1230 time-resolved fluorometer (Wallac, Turku, Finland). To assess the specificity of the TR-FIA, inhibition curves for boar serum and testicular extracts were compared with the curve for the boar INSL3 standard. Cross-reactivity with the 6-kDa porcine RLN purified from pregnant sow ovaries (Kohsaka et al. 1993), insulin

Published by Bioscientifica Ltd. 
(Sigma), luteinizing hormone (LH; UCB-Bioproducts, Braine-I'Alleud, Belgium), and follicle-stimulating hormone (FSH; UCB-Bioproducts) was also tested.

\section{Testosterone, $\mathrm{E}_{2}$, LH, and FSH assay}

Serum concentrations of testosterone and $E_{2}$ were measured with a TR-FIA kit (Perkin-Elmer), as previously reported (Sasaki et al. 2001). Testosterone and $\mathrm{E}_{2}$ were extracted from the serum samples with diethyl ether before being applied to the kits. LH and FSH were also determined by TR-FIA, as previously reported (Noguchi et al. 2010). Porcine FSH and LH immunoassay kits were provided by Dr A F Parlow (National Hormone and Peptide Program, Harbor-UCLA Medical Center, Torrance, CA, USA).

\section{Western blotting}

Testicular samples from whole-testis fragments of the developmental stages, blood and body fluid samples, native INSL3, recomb. INSL3, and synthetic human A-B heterodimeric INSL3 peptide (6292 Da; Phoenix Pharmaceuticals) were separated by SDS-PAGE on $14 \% \mathrm{w} / \mathrm{v}$ gels under non-reducing conditions, and electroblotted to nitrocellulose membranes (Bio-Rad), as described previously (Kato et al. 2010, Minagawa et al. 2012). Briefly, membranes were immunoreacted with anti-INSL3 antiserum (1:5000) and peroxidase-conjugated goat anti-rabbit IgG (1:20 000; ICN/Cappel, Aurora, OH, USA), and the signals were detected using an ECL (GE Healthcare, Little Chalfont, Buckinghamshire, UK). As a loading control, $\beta$-actin (ACTB) and transferrin (TF) were detected for testicular and serum samples respectively. For quantitative evaluation, the optical density (OD) was measured by densitometric scanning using Image J software (http://rsb. info.nih.gov/ij/).

\section{Immunohistochemistry and morphometric analysis}

Deparaffinized sections $(4 \mu \mathrm{m})$ were immunostained with anti-INSL3 antiserum (1:1000) or the antiserum preabsorbed with the recomb. INSL3 $(2 \mathrm{mg} / \mathrm{ml})$ followed by a goat anti-rabbit IgG polymer conjugated to peroxidase (DakoCytomation, Carpinteria, CA, USA), as described previously (Kato et al. 2010, Minagawa et al. 2012). Signals were visualized using diaminobenzidine (DakoCytomation) and examined under a BZ-9000 All-in-one Microscope (Keyence, Osaka, Japan). For morphometric analysis, photographs were taken of at least 20 different fields at each stage of development per animal $(n=3)$ under a
BZ-9000 All-in-one Microscope (Keyence). The area of INSL3-positive cells at each stage was analyzed using Dynamic cell count BZ-HIC software (Keyence), and then the mean percent area occupied by the positive cells was obtained by dividing by the total area of each photograph. Furthermore, the INSL3 staining intensity, the total number of Leydig cell, percentage of INSL3-positive Leydig cells per total number of Leydig cells, and diameter of Leydig cells and seminiferous tubules were measured within their field of view. The staining intensity of INSL3-positive cells was also analyzed using Dynamic cell count BZ-HIC software (Keyence), in which the value was expressed as arbitrary unit. The number of INSL3-positive Leydig cells and total Leydig cells were manually counted on a monitor fitted with an overhead projector sheet, and was expressed as cell number per $\mathrm{mm}^{2}$. For measurement of average cell diameter of Leydig cells, both the longest and shortest diameters were manually measured for each Leydig cell, using Dynamic cell count BZ-HIC software (Keyence) and the final diameter was considered to be the average of the two. The diameter of seminiferous tubules was also measured in the same manner. If the tubule was sectioned obliquely, the measurement was made across the narrowest dimension.

\section{Fractionation of testicular cells}

The germ cell, Sertoli cell, and Leydig cell fractions were prepared from the pubertal boar testis by collagenase treatment and mechanical dispersion as described previously (Kato et al. 2010). The quality of fractionated cells was verified by determining the expression of $H S D 3 B$ (HSDB1), PRM1, and INHA, which are expressed specifically by Leydig cells (Raeside \& Renaud 1983, Chemes et al. 1992), germ cells (Domenjoud et al. 1991), and both Sertoli and Leydig cells (Jin et al. 2001) respectively. The fractionated testicular cells were frozen and stored in liquid nitrogen.

\section{RNA extraction and semiquantitative RT-PCR}

Total RNA was extracted from either whole-testis fragments of the developmental stages studied or fractionated testicular cells using ISOGEN (Nippon Gene, Tokyo, Japan), treated with RNase-free DNase I (Qiagen), and reverse-transcribed using an oligo(dT) ${ }_{18}$ primer with ReverTra Ace (Toyobo, Tokyo, Japan). The primers used for amplification are presented in Table 1 . The primer set for amplification of the RXFP2 transmembrane regions 1-2 (RXFP2 TM 1-2) was designated to span the intron splice junctions between exons 15 and 16 to prevent amplification of the target from contaminating genomic DNA.

Published by Bioscientifica Ltd. 
Table 1 List of primers employed for boar target genes

\begin{tabular}{l} 
Gene \\
\hline INSL3 \\
RXFP2 TM 1-2 \\
RXFP2 endodomain \\
PRM1 \\
HSD3B \\
INHA \\
GAPDH
\end{tabular}

Forward primer $\left(5^{\prime} \rightarrow 3^{\prime}\right)$
caggaggcgccagagaagctgtgc
tcatttgaggacctcttggc
acagtgccttgaacccaatc
actgagtccatccatcacca
accagaagttcgggaggaat
cctcccagtttcatcttcca
gtgaaggtcggagtcaacggat

Reverse primer $\left(3^{\prime} \rightarrow 5^{\prime}\right)$
gggacagagggtcagcaagtcttg
cgtatttctgatactgcccg
tcactatattgtcccogagg
tagcaggctcctgtcagtca
ctctatgctgctggtgtgga
agtgctgggtgagaaggttg
ccaaattcattgtcataccagga

\begin{tabular}{ccc}
$\begin{array}{c}\text { Annealing } \\
\left({ }^{\circ} \mathrm{C}\right)\end{array}$ & & $\begin{array}{c}\text { Product } \\
(\mathrm{bp})\end{array}$ \\
\cline { 1 - 1 } 57 & & 312 \\
60 & & 235 \\
60 & & 204 \\
53 & & 283 \\
56 & & 262 \\
55 & & 241 \\
53 & & 947 \\
\hline
\end{tabular}

GenBank accession no.

X68369

XM_001927967

XM_001927967

NM_214253

AB529538

NM 214189

AF017079
The primer set amplifying the endodomain of the RXFP2 was in the region defined by exon 18 . The optimal number of PCR cycles for exponential amplification of target genes was determined as previously described (Kato et al. 2010). Amplification was performed using a DICE PCR Cycler (TaKaRa Bio, Shiga, Japan) in a $25 \mu$ l-reaction mixture containing Taq DNA polymerase (Roche) with the following cycling program: initial denaturation at $94{ }^{\circ} \mathrm{C}$ for $2 \mathrm{~min}$, followed by three-step amplification conditions consisting of 25 cycles of $94^{\circ} \mathrm{C}, 57^{\circ} \mathrm{C}$, and $72^{\circ} \mathrm{C}$ (20 s each) for INSL3; 33 cycles of $94^{\circ} \mathrm{C}, 60^{\circ} \mathrm{C}$, and $72{ }^{\circ} \mathrm{C}$ (30 s each) for RXFP2 TM 1-2 and RXFP2 endodomain; 25 cycles of $94^{\circ} \mathrm{C}$, $52^{\circ} \mathrm{C}$, and $72^{\circ} \mathrm{C}(1 \mathrm{~min}$ each) for $G A P D H$, followed by a final extension step at $72^{\circ} \mathrm{C}$ for $5 \mathrm{~min}$. To contrast, amplification of PRM1, INHA, and $H S D 3 B$ was carried out using the conditions described previously (Kato et al. 2010). The PCR products were electrophoresed on $2 \% \mathrm{w} / \mathrm{v}$ agarose gels containing ethidium bromide and visualized under u.v. light. For quantitative evaluation, the OD of the PCR products was measured by densitometric scanning using Image J software (http://rsb.info.nih.gov/ij/).

\section{Receptor binding assay}

Membrane preparations were prepared as described previously (Büllesbach \& Schwabe 1999) using germ cell fractions. Purified INSL3 was labeled with $4^{\prime}-\left(4^{\prime}-(4,6-\right.$ dichloro-1,3,5-triazin-2-ylamino)-4-biphenylyl]-2,2' $: 6^{\prime}$, $2^{\prime \prime}$-terpyridine-6,6"-diylbis(methyliminodiacetato) (DTBTA)$\mathrm{Eu}$, which had been converted from $4^{\prime}$-(4'-amino-4biphenylyl)-2,2':6',2"'-terpyridine-6,6" -diylbis(methyliminodiacetato) (ATBTA)-Eu (Tokyo Chemical Industry, Tokyo, Japan) according to the previous method (Yamaguchi et al. 2009). DTBTA-Eu, which is a recently developed luminescent lanthanide chelate label, has several advantages: it has sufficiently high stability in terms of metal dissociation and photo-degradation and it does not lose significant luminescence intensity in common buffers containing phosphate or EDTA compared with the previous lanthanide label (Eu) (Hashino et al. 2006, Yamaguchi et al. 2009). DTBTA-Eu was presumed to have labeled Lys ${ }^{\mathrm{B} 12}$ and the N-terminus of native boar INSL3 comprising the B-C-A single-chain form, because DTBTA-Eu, like $\mathrm{Eu}$, binds to the free amino groups of proteins. Bioactivity was confirmed on the basis of cAMP production in HEK-293 cells expressing RXFP2 as described previously (Minagawa et al. 2012).

The ligand-binding experiment was performed by employing a time-resolved fluorescence (TRF) assay as described previously (Lee et al. 2006). Briefly, for saturation binding, germ cell membrane preparations were incubated with DTBTA-Eu-INSL3 (0.5-16 nM) both in the absence (total binding) and presence (nonspecific binding) of $500 \mathrm{nM}$ unlabeled ligand. For competitive binding, membranes were incubated with unlabeled INSL3 (0.1-500 nM) plus $4 \mathrm{nM}$ DTBTA-Eu-INSL3. All incubations were performed for $30 \mathrm{~min}$ at $25^{\circ} \mathrm{C}$ in AcroWell 96-well filter plates (Pall, Port Washington, NY, USA) and terminated by rapid filtration using vacuum manifolds (Pall). Enhancement solution (100 $\mu \mathrm{l} /$ well; Perkin-Elmer) was added and the fluorescence was measured. The data were analyzed using the non-linear curve fitting functions in PRISM version 5.0 (GraphPad Software, San Diego, CA, USA).

\section{Statistical analysis}

Values are presented as the means \pm s.e.m. Data were analyzed by one-way ANOVA, together with Fisher's Protected Least Significant Difference multiple range test to compare the means of different groups. $P<0.05$ was considered statistically significant.

\section{Results}

Characteristics of the TR-FIA for boar INSL3

Characterization of the INSL3 antibody Antiserum from Rabbit \#1 was suitable for use in the INSL3

Published by Bioscientifica Ltd 
assay. The antiserum (Ab-R178) specifically recognized the 12 -kDa-purified boar INSL3 as well as the $\sim 16 \mathrm{kDa}-$ recomb. INSL3 (immunizing antigen), as verified by western blotting (Fig. 1A). These bands were not observed when antiserum preabsorbed with immunizing antigen was applied. Furthermore, we compared the calibration curves generated from western blot analysis, which was carried out simultaneously for native INSL3 and recomb. INSL3 to investigate antibody sensitivity. The resulting
A

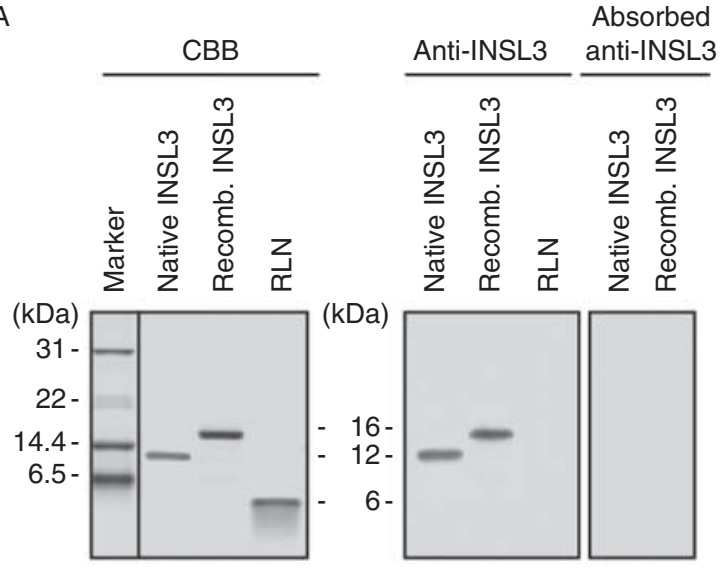

C

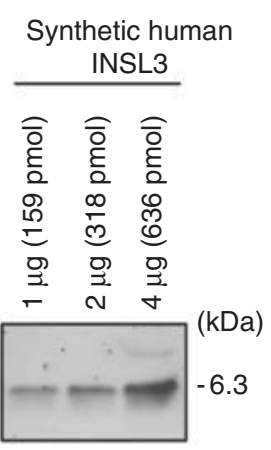

$\left(\times 10^{4}\right) \quad y=52505 \operatorname{Ln}(x)+35868$

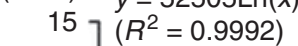

○ิ

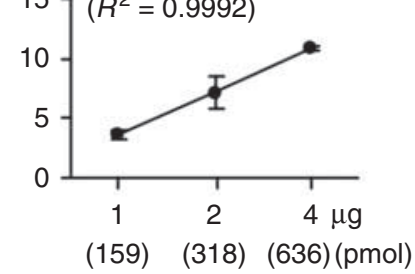

Synthetic human INSL3
D $\begin{gathered}\text { Serum }(\mu \mathrm{l} / \mathrm{well}) \text { or } \\ \text { homogenate }(\mathrm{mg} / \text { well })\end{gathered}$

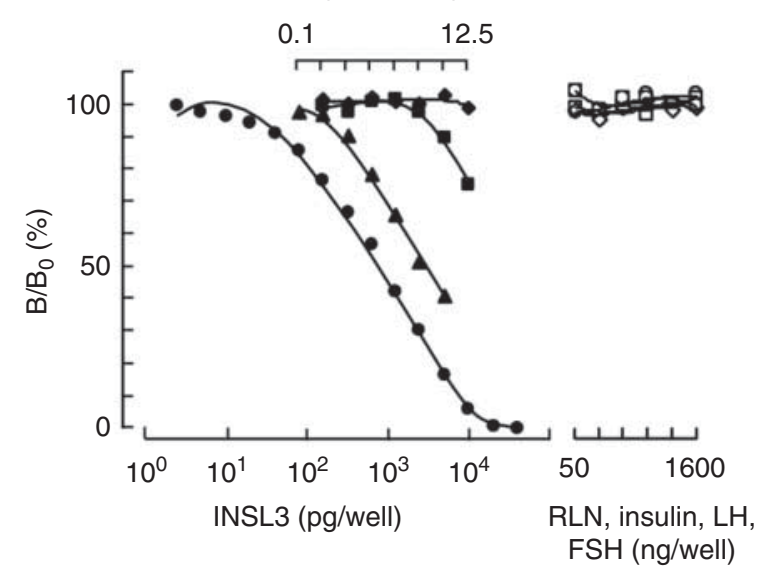

calibration curves for native INSL3 and recomb. INSL3 were linear in the ranges of $0.25-1 \mathrm{ng}(0.02-0.08 \mathrm{pmol})$ and $0.125-0.5 \mathrm{ng}(0.008-0.03 \mathrm{pmol})$ (Fig. 1B) respectively. Therefore, we found that antibody sensitivity was quite satisfactory, although an $~ 2.7$-fold higher picomoles concentration of the native INSL3 was required to generate signals as intense as those of the recomb. INSL3. In addition, we used a synthetic A-B heterodimeric human INSL3 peptide (6292 Da; Phoenix Pharmaceuticals)
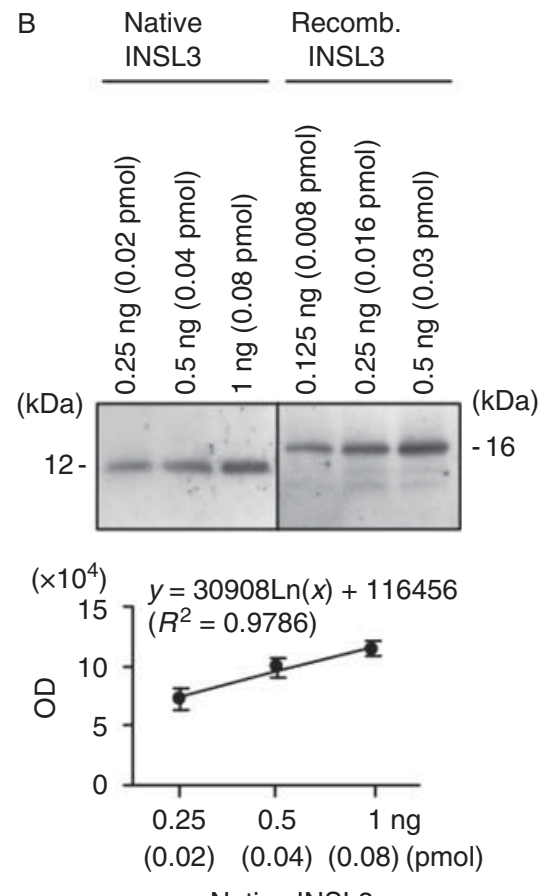

Native INSL3

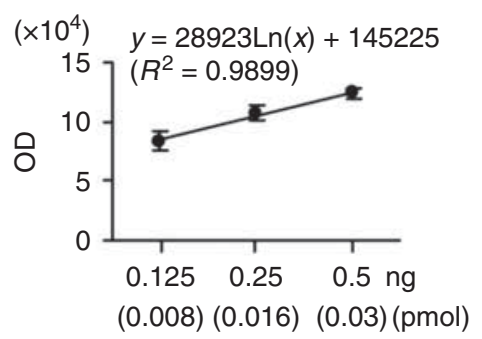

Recomb. INSL3

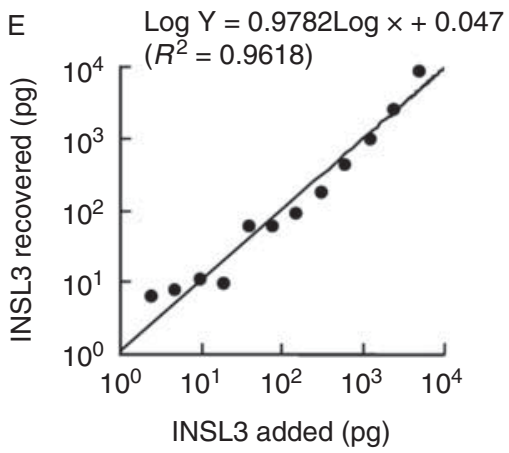

http://joe.endocrinology-journals.org DOI: 10.1530/JOE-13-0430
() 2014 Society for Endocrinology Printed in Great Britain 
to determine whether the antiserum cross-reacted with the $6 \mathrm{kDa} \mathrm{A}-\mathrm{B}$ heterodimer by using western blotting. From western blot analysis, we examined the calibration curves generated for synthetic human INSL3 peptide and found a marked difference in sensitivity. The calibration curve for synthetic human INSL3 peptide was linear in a range of 1-4 $\mu \mathrm{g}$ (159-636 pmol) (Fig. 1C). This shows that the A-B heterodimer can be detected but requires an $\sim 7950$-fold higher picomoles concentration of the A-B heterodimer to generate a signal comparable to that of the native $\mathrm{B}-\mathrm{C}-\mathrm{A}$ form. The antiserum did not cross-react with the $6 \mathrm{kDa}$ porcine RLN (Fig. 1A), indicating that this antiserum was specific for boar INSL3.

Standard curve, sensitivity, and specificity A suitable standard curve of boar INSL3 produced a reverse sigmoid response in the range of $2.5-40000 \mathrm{pg} / \mathrm{well}$ (Fig. 1D), which is an unusually large detection range for an immunoassay. The reasons for this wide range are unclear, but it may be related to the antibody affinity. The sensitivity of boar INSL3 was $8.2 \mathrm{pg} /$ well. Serial dilutions of serum and testicular extract from mature boars yielded inhibition curves parallel to the standard curve. Castrated boar serum caused no displacement of the labeled hormone. Porcine RLN, insulin, LH, and FSH also showed no cross-reaction at microgram amounts in this assay.

Precision and reproducibility The precision and reproducibility of the TR-FIA were examined using serum samples from adult boars. The intra- and inter-assay coefficients of variation at top-, mid-, and bottom-range were 3.04 and $3.46 \%, 2.52$ and $3.16 \%$, and 5.56 and $14.71 \%$ respectively.

Accuracy Accuracy was assessed by determining the recovery of known amounts of INSL3 added to $6.25 \mu \mathrm{l}$ aliquots of serum (1/8-diluted serum) from a castrated boar. An excellent correlation between the amounts of hormone added and those recovered was observed, resulting in a regression line $\left(r^{2}=0.962\right)$ (Fig. 1E).

\section{Profiles of INSL3, steroids, and gonadotropin in boars during development}

Serum INSL3 levels started to increase slightly from the onset of puberty and elevated significantly $(P<0.05)$ to postpuberty, subsequently remaining at a steady level in adulthood (Fig. 2). In contrast, serum testosterone levels increased progressively toward puberty with an irregular fluctuation at subsequent ages. $\mathrm{E}_{2}$ levels followed a similar pattern of INSL3, increasing in a stepwise fashion with advancing age. LH levels were elevated with a decline from the pubertal stage onwards, while FSH levels showed little change during development (Fig. 2).

\section{Developmental expression of the INSL3 gene and protein in the testis}

INSL3 transcripts were only expressed in the testis of pubertal boars (Fig. 3A). Semiquantitative RT-PCR

\section{Figure 1}

INSL3 assay characteristics. (A) Specificity of antiserum for INSL3. Purified boar INSL3 (native INSL3), recombinant INSL3 (recomb. INSL3), and porcine relaxin (RLN) separated by SDS-PAGE under non-reducing conditions and stained with Coomassie brilliant blue (left panel). For each lane, $2 \mu \mathrm{g}$ proteins were applied. CBB, Coomassie brilliant blue-stained SDS-PAGE. Verification of the specificity of anti-INSL3 antiserum by western blot analysis (center panel). For each lane, $1 \mathrm{ng}$ of native INSL3, $0.5 \mathrm{ng}$ of recomb. INSL3, and $2 \mu \mathrm{g}$ of RLN were loaded respectively. The anti-INSL3 serum from rabbit \#1 (Ab R178 antiserum) strongly recognized 12-kDanative INSL3. This antiserum also recognized the $\sim 16 \mathrm{kDa}$-recomb. INSL3. However, this antiserum did not cross-react with porcine RLN. Verification by preabsorbed antiserum (right panel). For each lane, $1 \mathrm{ng}$ of native INSL3 and $0.5 \mathrm{ng}$ of recomb. INSL3 were loaded respectively. Native INSL3 and recomb. INSL3 were not observed when antiserum preabsorbed with recomb. INSL3 (2 mg/ml) was applied. (B) Comparison of western blot calibration curves of a native INSL3 and recomb. INSL3. A representative western blot analysis (upper panel). The samples were separated by SDSPAGE on a $14 \%$ gel under non-reducing conditions and transferred to nitrocellulose membranes. The protein loads were $0.25,0.5$, and $1 \mathrm{ng}$ (corresponding to $0.02,0.04$, and 0.08 pmol) for native INSL3; and 0.125 , 0.25 , and $0.5 \mathrm{ng}$ (corresponding to $0.008,0.016$, and $0.03 \mathrm{pmol}$ ) for the recomb. INSL3 respectively. Calibration curves for the native INSL3 (middle panel) and recomb. INSL3 (bottom panel). Regression lines were calculated using eight measurements for each band. Comparison of the native INSL3 and recomb. INSL3 shows that an $\sim 2.7$-fold higher picomoles concentration of the native INSL3 was required to detect a signal intensity comparable to that of the recomb. INSL3. (C) Western blot calibration curve of a synthetic A-B heterodimeric human INSL3 peptide (6.3 kDa; Phoenix Pharmaceuticals). A representative western blot analysis (right panel). Samples were separated by SDS-PAGE on a $14 \%$ gel under non-reducing conditions and transferred to the nitrocellulose membranes. The loads were 1,2 , and $4 \mu \mathrm{g}$ (corresponding to 159,318 , and 636 pmol respectively). Calibration curve for synthetic human INSL3 (left panel). Regression line was calculated using three measurements for each band. Comparison of (B) and $(C)$ shows that an $\sim 7950$-fold higher picomoles concentration of the $A-B$ heterodimer was required to generate a signal comparable to that of the native B-C-A form. (D) Dose-response curves from the INSL3 TR-FIA. Porcine INSL3 standard (closed circle); pig testis (closed triangle); male pig serum (closed square); castrated pig serum (closed diamond); porcine RLN (open circle); porcine insulin (open square); porcine LH (open diamond); and porcine FSH (open thick square). Each point is the average of triplicate determinations. (E) Recovery of boar INSL3 was added to serum. Various amounts of INSL3 were added to 6.25 - $\mu$ l aliquots of serum (1/8-diluted serum) from a castrated male pig and the amounts of hormone recovered were measured by TR-FIA. Each point is the average of triplicate determinations. $O D$ indicates the densitometry of the western blot analysis.

Published by Bioscientifica Ltd. 

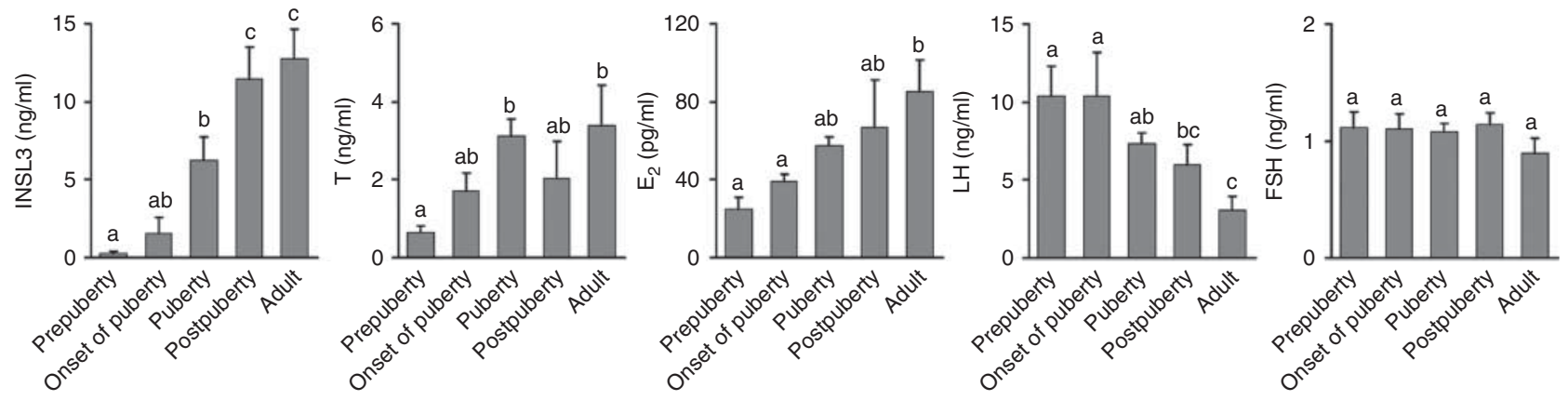

Figure 2

Profiles of serum INSL3, testosterone $(T)$, estradiol-17 $\beta\left(E_{2}\right), L H$, and FSH concentrations in boars during development. Peripheral sera were collected from boars in prepuberty (7-15 weeks, $n=7)$, at the onset of puberty (17-21 weeks, $n=7)$, in puberty (24-30 weeks, $n=15)$,

indicated that the relative level of INSL3 expression was still low at 7 weeks of age (prepuberty), but increased significantly $(P<0.05)$ and reached its maximum at 18 weeks (onset of puberty), and then remained at a steady level up to 38 weeks (postpuberty) (Fig. 3B). In contrast, western blot analysis revealed that the expression level of the INSL3 protein followed a similar pattern to that of the INSL3 gene, but the INSL3 protein increased relatively slowly around the onset of puberty compared with the INSL3 (Fig. 3C).

\section{Immunostaining pattern and percent area of INSL3-positive Leydig cells in the testis during development}

Immunostaining for INSL3 was positive in Leydig cells at all stages of development studied. A positive signal was observed as a punctuate spot with moderate intensity at 7 weeks, but the signal seemed to extend throughout the cytoplasm with moderate intensity concomitant with a rapid differentiation of Leydig cells at 18 weeks (Fig. 4A). Thereafter, the signals appeared to become more intense up to 46 weeks. Staining of Leydig cells was not observed when the antiserum was preabsorbed by incubation with recomb. INSL3 (Fig. 4A). When we carried out morphometric analysis, we observed that the testes not only massively increased in size due to the onset of spermatogenesis (the onset of puberty, i.e., 18 weeks) but also changed in the relative proportion of Leydig cells. There was also a significant change $(P<0.05)$ in the percent area occupied by INSL3-positive Leydig cells, percentage of INSL3-positive Leydig cells per total number of Leydig cells, and the INSL3 staining intensity at 18 weeks, which in subsequent postpuberty (36-38 weeks, $n=8$ ), and in adultlife (48 weeks-3.3 years, $n=13$ ). Values are the means \pm s.E.M. and values with different letters are significantly different $(P<0.05)$.

reached a maximum level at 30 weeks, subsequently remaining at a similar level up to 46 weeks (Fig. 4B). This result corresponds to the findings from the western blotting, revealing that the developmental expression of the INSL3 protein in the testis is attributable to an increase in both protein level per cell and percentage of proteinexpressing cells.

\section{INSL3 in testicular body fluid compartments}

The intratesticular transport of INSL3 was examined by the TR-FIA and western blotting with fluid from various compartments of the reproductive system in adult boars. TR-FIA demonstrated that the concentration of INSL3 detected in interstitial fluid and seminiferous tubule fluid was eight- to tenfold higher $(P<0.05)$ than that in peripheral serum (Fig. 5A). This level was as high as that in testicular venous serum. In contrast, the concentration of INSL3 was reduced to less than half in rete testis fluid, and then was not detected in the efferent duct fluid and epididymal fluid (Fig. 5A). Western blotting of plasma and testicular body fluids clearly demonstrated the presence of the $12 \mathrm{kDa}$ INSL3 (Fig. 5B). However, we cannot exclude the possibility that some INSL3 might exist as a processed A-B heterodimer in low quantities in serum and body fluid because of the insensitivity of western blotting used for its detection.

\section{Expression of RXFP2 gene in testicular germ cells}

The expression of RXFP2 transcripts was examined by RT-PCR analysis of fractionated boar testicular cells, using two types of primer sets to exclude splice variants, particularly variants involving the TM 1-2 coding region.

Published by Bioscientifica Ltd. 

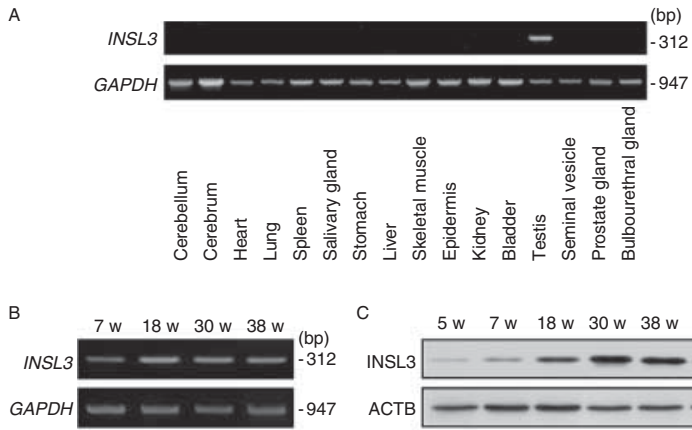

C $\quad 5$ w $\quad 7$ w 18 w 30 w 38 w 46 w
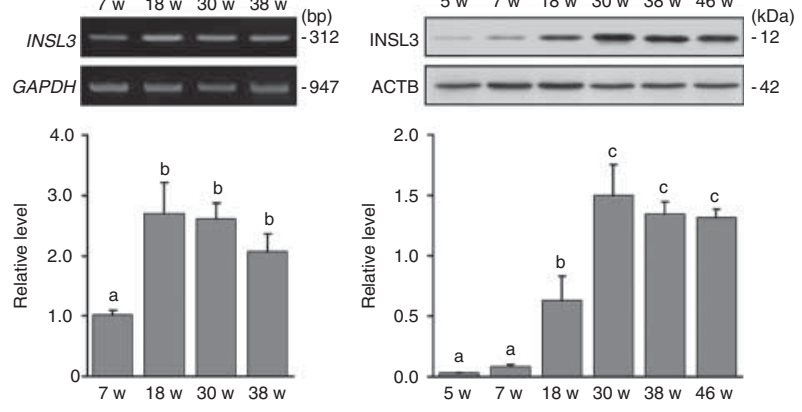

\section{Figure 3}

Developmental expression of the INSL3 gene and protein in the boar testis. (A) Tissue distribution of INSL3 gene expression in the boar. RT-PCR analysis was carried out with total RNA from various tissues of 30-week-old pubertal boar. A single amplification product of 312 bp encoding INSL3 mRNA was detected only in the testis. No expression was detected in other organs or tissues. (B) Developmental expression of the INSL3 gene in the boar testis. Representative semiquantitative RT-PCR analysis (upper panel). RT-PCR analysis was carried out with total RNA from whole-testis fragments during pubertal development. Relative level of expression normalized to that of GAPDH (lower panel). The relative level of INSL3 expression was low up to 7 weeks of age, corresponding to the prepubertal stage. Thereafter, it increased significantly to the maximum value at 18 weeks (onset of puberty), and then remained stable up to the age of 38 weeks (postpuberty). Values are the means \pm s.E.M. from three animals at each time point, and values with different letters represent a significant difference $(P<0.05)$. (C) Developmental expression of INSL3 protein in the boar testis. Representative western blot analysis (upper panel). Western blot analysis was carried out with extracts from whole-testis fragments during pubertal development. For each lane, $35 \mu \mathrm{g}$ of sample was applied. Using characterized anti-INSL3 R178 antiserum, INSL3 protein was detected as a specific band of $12 \mathrm{kDa}$ at all ages despite changes in translational activity. The relative level of expression was normalized to that of ACTB (lower panel). The signal increased slightly at around 18 weeks (onset of puberty), but intense expression occurred from 30 weeks onward (puberty onwards). Values are the means \pm s.E.M. from three animals at each time point, and values with different letters are significantly different $(P<0.05)$. w, weeks of age.

The reason we focused on the variant involving the TM 1-2 coding region was as follows: RXFP2 splice variants missing exon 15 encoding TM 1 followed by the beginning of TM 2 have recently been identified from the ovary of rhesus monkeys (Hanna et al. 2010). In addition, the predicted porcine RXFP2 mRNA sequence (XM_001927967) lacked a LDL class-A (LDL-A) module and some leucine-rich repeats (LRR) in the ectodomain, although splicing variants derived from the RXFP2 ectodomain, such as LGR8.1 missing an LRR encoded by exon 11 (Muda et al. 2005) and LGR8-short missing exon 2 encoding LDL-A module (Scott et al. 2006), have been reported in human uterus. The fractionation was found to be quite satisfactory; that is, $H S D 3 B$ and PRM1 expression were limited to the Leydig cell and germ cell fractions, respectively, while expression of INHA was found in both the Sertoli and Leydig cell fractions (Fig. 6). In testicular fractions without contamination, INSL3 expression was restricted to the Leydig cell fraction where HSD3B was detected, whereas RXFP2 transcripts were expressed in the germ cell fraction with a weak signal in the Sertoli cell fraction as detected by primers amplifying either TM 1-2 or the endodomain of RXFP2 (Fig. 6). RT-PCR data with primers amplifying the endodomain of the RXFP2 was not able to resolve the issue of whether splice variants involving the ectodomain- or TM 1-2 coding region are present, because this primer set was in the region defined by exon 18 . However, RT-PCR data with primers amplifying RXFP2 TM 1-2, which was designated to span the intron splice junctions between exons 15 and 16, revealed that splice variants involving the TM 1-2 coding region are not present in boar testicular cells, although splice variants involving the ectodomain-coding region have not been identified.

\section{INSL3 ligand binding to germ cells}

The functionality of the RXFP2 protein was examined by a TRF-binding assay using membrane aliquots of the fractionated germ cells. In the saturation-binding assay, germ cell membranes were incubated with increasing concentrations of DTBTA-Eu-INSL3. Nonspecific binding was tested in the presence of $500 \mathrm{nM}$ INSL3. DTBTAEu-INSL3 binds in a specific and saturable manner and its binding was fitted to a one-site binding equation (Fig. 7A). The calculated $K_{\mathrm{d}}$ and maximal binding $\left(B_{\max }\right)$ for DTBTAEu-INSL3 were $5.44 \pm 1.07 \mathrm{nM}$ and $8.44 \times 10^{4} \pm 7044 \mathrm{CPS}$ respectively. In the competitive-binding assay, the membranes were incubated with increasing doses of unlabeled INSL3 plus $4 \mathrm{nM}$ DTBTA-Eu-INSL3, and the binding was fitted to a one-site competition binding equation. INSL3 effectively displaced the DTBTA-Eu-INSL3 with an $\mathrm{IC}_{50}$ value of $8.67 \mathrm{nM}$ (Fig. 7B).

\section{Discussion}

This study demonstrated that INSL3 is upregulated during development and transported into the seminiferous compartments, where it binds to germ cells, thereby

Published by Bioscientifica Ltd. 
A

$5 \mathrm{w}$
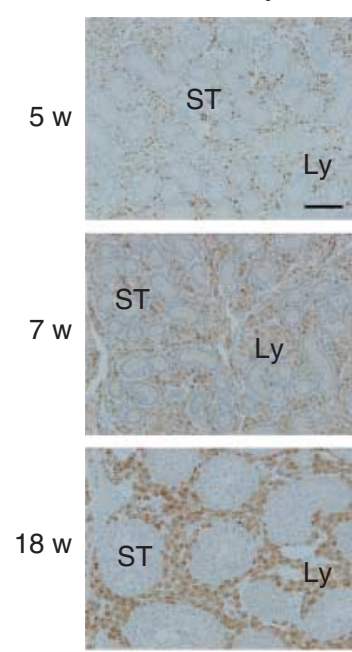

B

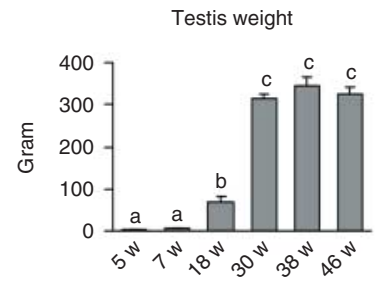

Leydig cell number

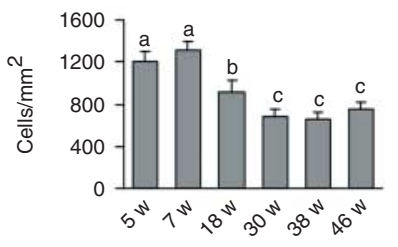

Absorbed antibody
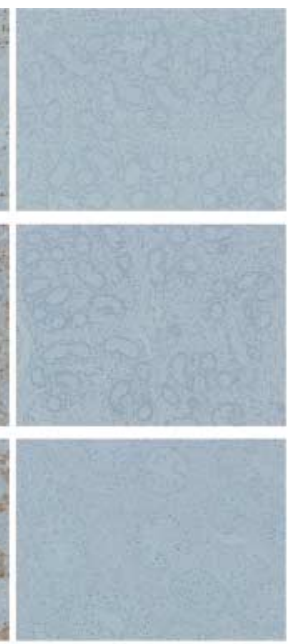

$30 \mathrm{w}$

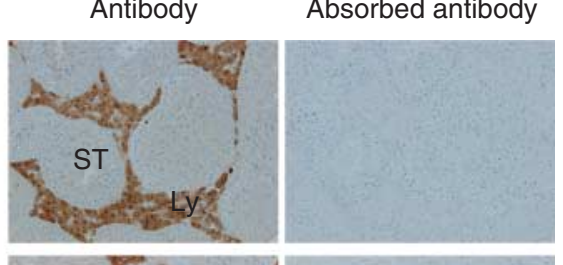

$38 \mathrm{w}$

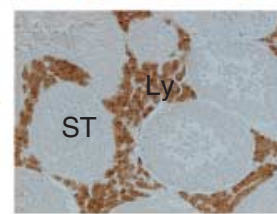

$46 \mathrm{w}$
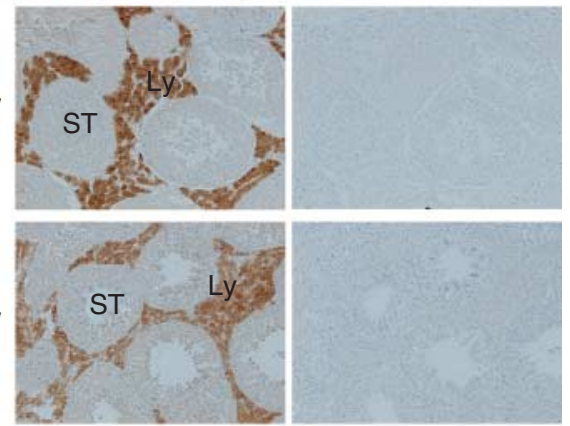

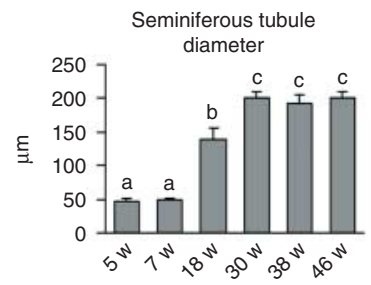

Percent area of INSL3-

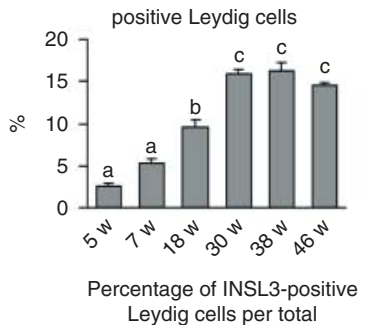

number of Leydig cells

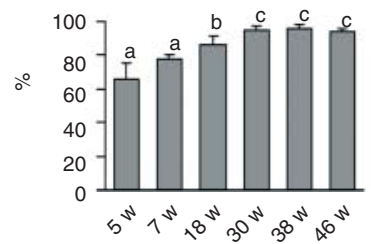

Leydig cell diameter

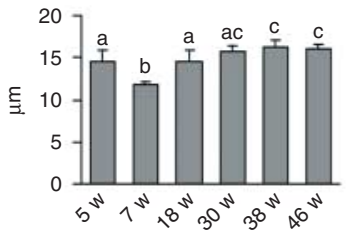

INSL3 staining intensity

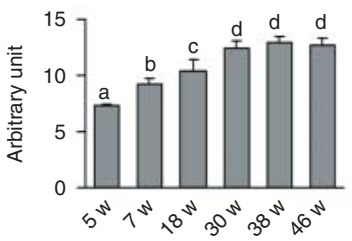

\section{Figure 4}

Immunostaining pattern and mean area of INSL3-positive Leydig cells in the boar testis during development. (A) Staining pattern. Using characterized anti-INSL3 R178 antiserum, immunostaining for INSL3 was only visualized in Leydig cells at all developmental stages studied. Positive signals were observed as punctuate spots with moderate intensity at 5 and 7 weeks (prepuberty), but the signal seemed to extend throughout the cytoplasm with moderate intensity concomitant with rapid differentiation of Leydig cells at 18 weeks (onset of puberty). Thereafter, the signals appeared to become more intense up to the age of 46 weeks (adultlife). Staining of Leydig cells was abolished by preabsorbing the antiserum with recombinant INSL3. w, weeks of age; Ly, Leydig cells; ST, seminiferous tubules. $B a r=100 \mu \mathrm{m}$; all panels are the same magnification. (B) Developmental changes of testis weight, seminiferous tubular diameter, Leydig cell population, and the percent area, and staining intensity of INSL3-positive Leydig cells in the boar. The testes massively increased in size due to the onset of spermatogenesis (the onset of puberty) and changed in the relative proportion of Leydig cells. There was a significant change in the percent area occupied by INSL3-positive Leydig cells, percentage of INSL3positive Leydig cells per total number of Leydig cells, and the INSL3 staining intensity during pubertal development reaching a maximum level at 30 weeks, but subsequently remaining at a similar level up to 46 weeks (adultlife). Values are the means \pm s.E.M. from three animals at each time point, and values with different letters are significantly different $(P<0.05)$. 


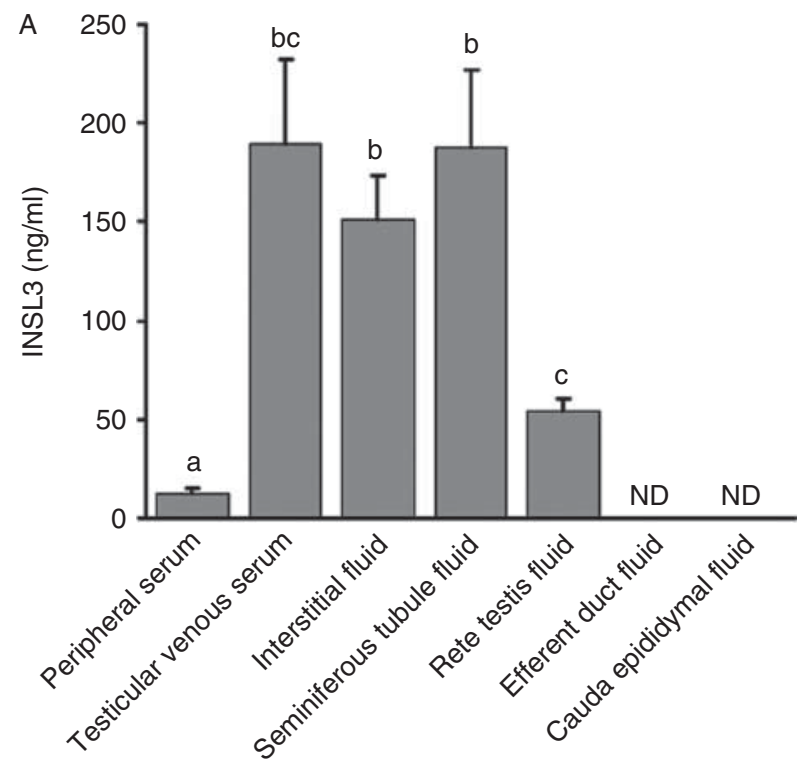

B

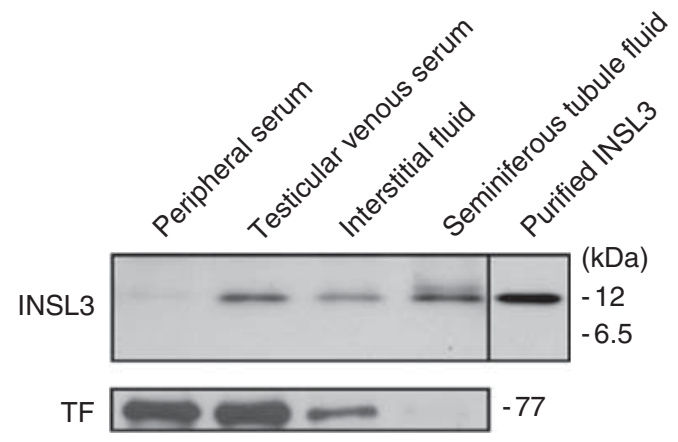

Figure 5

INSL3 in various fluid compartments of the male reproductive system in adult boars. (A) TR-FIA measurement. INSL3 concentration in the interstitial fluid and seminiferous tubule fluid was as high as that in the testicular venous serum. Values are the means \pm s.E.M. from eight animals at each time point, and values with different letters are significantly different $(P<0.05)$. (B) A representative western blot analysis indicating the presence of $12 \mathrm{kDa}$ INSL3 in both interstitial and seminiferous compartments. For each lane, $0.1 \mu \mathrm{l}$ of serum or body fluids and $1 \mathrm{ng}$ of purified INSL3 were applied. $\mathrm{TF}$, transferrin.

characterizing the presence of the INSL3 hormonereceptor system in the boar testis.

Initially, we succeeded in developing a reliable immunoassay for measuring boar INSL3 using a TR-FIA platform and demonstrated that circulating INSL3 concentrations increased progressively in boars during pubertal development, which is fundamentally consistent with other studies in humans (Ferlin et al. 2006, Wikström et al. 2006) and rodents (Boockfor et al. 2001, Anand-Ivell et al. 2009). In common with circulating INSL3, we found that INSL3 mRNA and protein expression in the testis were upregulated coincidently with pubertal development, although the INSL3 protein increased relatively slowly around the onset of puberty compared with the mRNA, as has been previously reported in the mouse testis (Balvers et al. 1998). Our present results suggest that the dynamics of INSL3 production and secretion corresponded fundamentally to the developmental status of boar Leydig cells (Peyrat et al. 1981, Lunstra et al. 1986, Franca et al. 2000) and may be maintained by the long-term effect of LH on Leydig cell structure and function. In fact, with the establishment of a functional hypothalamic-pituitarygonadal (HPG) axis during puberty, boar Leydig cells appear to be most responsive to LH at puberty as characterized by a dramatic increase in cell number, cell volume, LH receptor number, and intracellular organelles of the Leydig cells (Peyrat et al. 1981, Lunstra et al. 1986, Franca et al. 2000), and also as indicated by our findings that the testosterone levels increased progressively toward puberty with an irregular fluctuation at subsequent ages, whereas $E_{2}$ levels increased in a stepwise fashion with advancing age, consistent with previous reports (FlorCruz \& Lapwood 1978, Allrich et al. 1982, Schwarzenberger et al. 1993, Estienne et al. 2000). In addition, in other species, INSL3 has been reported to be constitutively expressed and secreted by the Leydig cells under the long-term effects of LH/hCG and is not acutely regulated by LH/hCG and other hormones influencing Leydig cell differentiation, such as insulin-like growth factor1 (IGH1) (Foresta et al. 2004, Bay et al. 2005, Sadeghian et al. 2005). In line with the lack of an acute stimulatory effect of LH, we did not find any correlation between LH and INSL3 in boars, although there are conflicting findings showing a positive correlation between them in normal men (Foresta et al. 2004, Ferlin et al. 2006).

Interestingly, we successfully demonstrated that INSL3 secreted from Leydig cells was released not only into the blood circulation but also into the interstitial and seminiferous compartments at sufficient concentrations. This was further emphasized by the results of our western blot analysis, which clearly indicated the presence of $12 \mathrm{kDa}$ INSL3 in both interstitial and seminiferous compartments. These findings suggest that INSL3 enters the seminiferous compartment across the blood-testis barrier (BTB), which is created by inter-Sertoli tight junctions and adherens junctions (Lui \& Lee 2009). Similar findings were also found in rat INSL3 (Anand-Ivell et al. 2009). However, why and how INSL3 secreted from Leydig cells traverse the BTB remains unknown. One possible explanation is merit consideration. Influx of INSL3 into the seminiferous compartment in boars may

Published by Bioscientifica Ltd. 


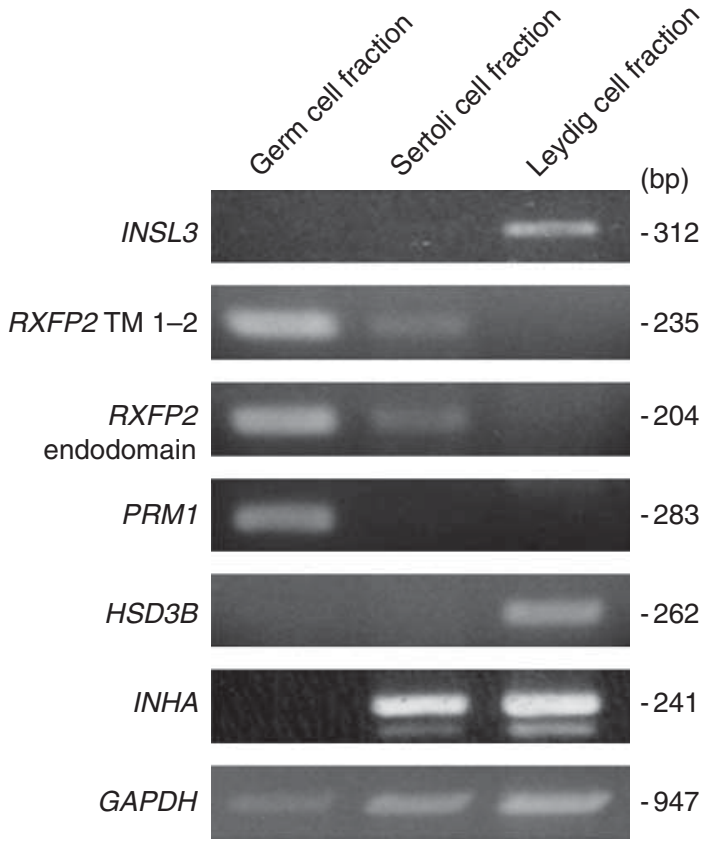

Figure 6

Expression of RXFP2 gene in testicular germ cells. Germ cell, Sertoli cell, and Leydig cell fractions were prepared from the pubertal boar testis. The quality of these fractionated cells was verified by detecting the expression of HSD3B, PRM1, and INHA, which are expressed specifically by Leydig cells, germ cells, and both Sertoli and Leydig cells respectively. No indication of contamination was observed in any of the fractions. Expression of INSL3 was detected only in the Leydig cell fraction where HSD3B was detected. On the other hand, RXFP2 expression was detected mainly in germ cell fractions with weak expression in the Sertoli cell fraction as detected by primer pairs amplifying either transmembrane regions 1 through 2 (TM 1-2) or the endodomain of RXFP2.

be attributable to the opening of the BTB and take place concomitantly when physiological disassembly of tight junctions occurs to allow the passage of preleptotene spermatocytes across the BTB. This is based on the findings that the BTB separates mitotic spermatogonia from meiotic germ cells and is periodically disassembled to allow the passage of preleptotene spermatocytes across the barrier (Lui \& Lee 2009, Mruk \& Cheng 2010, Cheng \& Mruk 2012).

Although no studies to date have identified the possible sites of action of INSL3 in the boar testis, RXFP2 mRNA and/or protein have been shown to be expressed in Leydig cells, germ cells, and/or Sertoli cells in different species, including humans (Anand-Ivell et al. 2006a), rats (Kawamura et al. 2004, Anand-Ivell et al. 2006a), mice (Anand-Ivell et al. 2006a, Feng et al. 2007), roe deer (Hombach-Klonisch et al. 2004), and goats (Siqin et al. 2010). In this study, however, we clearly showed that
RXFP2 transcripts were expressed mainly in seminiferous germ cells with a weak signal in Sertoli cells, but not in Leydig cells, although the specific germ cell types that expressed the RXFP2 protein could not be identified because of the absence of reliable anti-RXFP2 antibodies. Furthermore, we found that INSL3 was able to bind to membranes prepared from seminiferous germ cells in a hormone-specific and saturable manner. Taken together with the findings concerning the fate of secreted INSL3, these findings show that INSL3 secreted into the interstitial compartment and then transported into the seminiferous compartments is capable of encountering
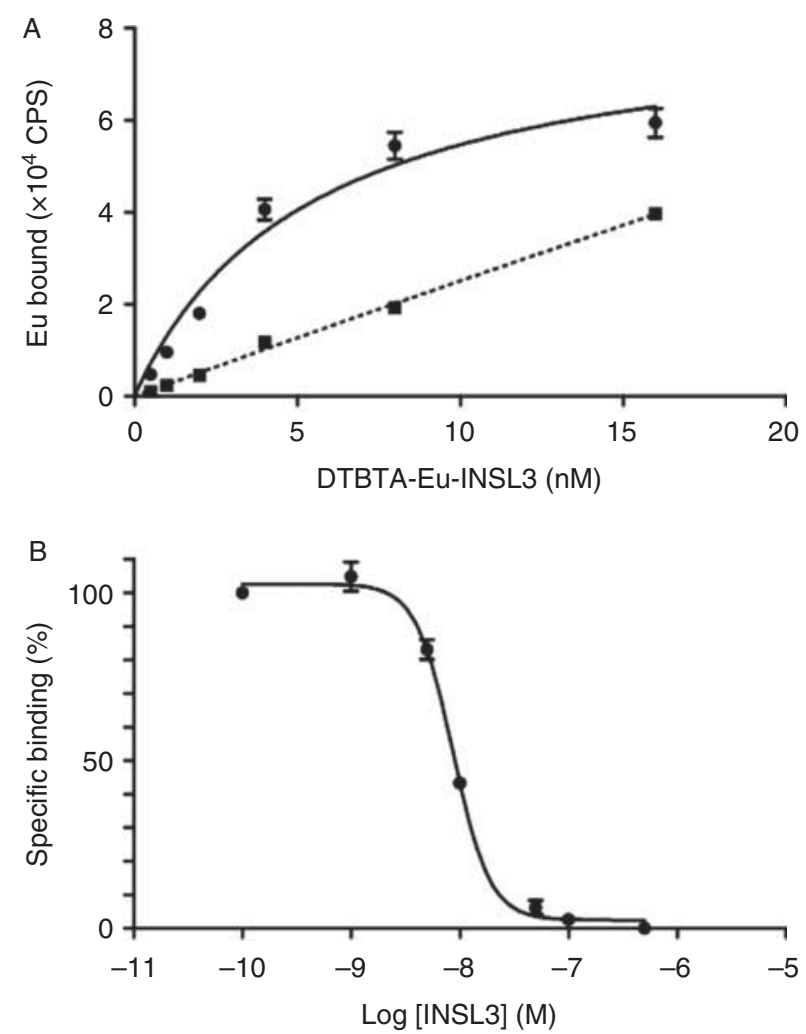

Figure 7

INSL3 ligand binding to germ cells. Time-resolved fluorescence (TRF) receptor-binding assay was carried out using DTBTA-Eu-INSL3. The membrane aliquots used for the receptor assay were prepared from the fractionated germ cells. (A) Saturation binding. DTBTA-Eu-INSL3 was found to bind to germ cell membranes in a specific and saturable manner and its binding was fitted to a one-site binding equation. The calculated $K_{\mathrm{d}}$ and maximal binding $\left(B_{\max }\right)$ for DTBTA-Eu-INSL3 were $5.44 \pm 1.07 \mathrm{nM}$ and $8.44 \times 10^{4} \pm 7044$ CPS respectively. Values are the means \pm S.E.M. from three independent experiments. Nonspecific binding was determined in the presence of $500 \mathrm{nM}$ unlabeled INSL3. Specific binding (-closed circle-), nonspecific binding (-closed square-). (B) Competitive binding. Binding was normalized between $100 \%$ (no added ligand) and $0 \%$ (500 nM ligand). INSL3 effectively displaced the DTBTA-Eu-INSL3 with an IC $\mathrm{C}_{50}$ value of $8.67 \mathrm{nM}$.

Published by Bioscientifica Ltd 
germ cells, where its receptor RXFP2 is expressed, thus enabling INSL3 to bind. This provides evidence that INSL3 could act as a paracrine factor in seminiferous germ cells in the boar testis. Unfortunately, it remains unknown what functions INSL3 actually exerts on germ cells in the boar testis. One possibility is that INSL3 plays a role in the maintenance of spermatogenesis by regulating cellular processes such as apoptosis through the receptor RXFP2 on seminiferous germ cells in a paracrine manner. In adult rats, $R x f p 2$ transcripts are localized in spermatocytes, and injection of INSL3 into testes treated with a GnRH antagonist was shown to suppress germ cell apoptosis, suggesting that INSL3 acts through RXFP2 on germ cells and thereby contributes to spermatogenesis as a survival factor for male germ cells (Kawamura et al. 2004). However, a more recent study in conditional $R x f p 2$ knockout mice, in which the gene was specifically deleted in later stages of postmeiotic germ cells, INSL3-RXFP2 signaling was found to be dispensable for spermatogenesis and male fertility (Huang et al. 2012).

In conclusion, we demonstrated that INSL3 gene and protein expressions are upregulated during puberty, as reflected by changes in circulating levels. We also provide evidence that INSL3 secreted from Leydig cells is released not only into the blood circulation but also into the interstitial compartment, and that INSL3 is transported into the seminiferous compartments, where it is able to bind to RXFP2 expressed on germ cells, suggesting that INSL3 acts as a paracrine factor in boar germ cells.

\section{Declaration of interest}

The authors declare that there is no conflict of interest that could be perceived as prejudicing the impartiality of the research reported.

\section{Funding}

This research was supported by a Grant-in-Aid for Scientific Research from the Japan Society for the promotion of Science (grant number 24580408 to T K).

\section{Author contribution statement}

I M, D S, A M P, and H K performed experiments, data acquisition, and analysis. M S participated in the experimental design and contributed to the sampling. $\mathrm{H} \mathrm{S}$ and $\mathrm{Y} \mathrm{H}$ contributed to data interpretation. T K conceived the project, analyzed the results, and wrote the manuscript with the assistance of $\mathrm{H} \mathrm{S}$. All of the authors approved the manuscript.

\section{Acknowledgements}

The authors thank Mr Y Hattori, Keyence, Osaka, Japan, for the use of the BZ-9000 All-in-one Microscope and BZ-HIC software. They also thank
Dr A F Parlow, National Hormone and Peptide Program, Harbor-UCLA Medical Center, Torrance, CA, USA, for providing the porcine FSH and LH immunoassay kits.

\section{References}

Adham IM, Burkhardt E, Benahmed M \& Engel W 1993 Cloning of a cDNA for a novel insulin-like peptide of the testicular Leydig cells. Journal of Biological Chemistry 268 26668-26672.

Allrich RD, Christenson RK, Ford JJ \& Zimmerman DR 1982 Pubertal development of the boar: testosterone, estradiol-17 $\beta$, cortisol and LH concentrations before and after castration at various ages. Journal of Animal Science 55 1139-1146.

Anand-Ivell RJ, Relan V, Balvers M, Coiffec-Dorval I, Fritsch M, Bathgate RA \& Ivell R 2006a Expression of the insulin-like peptide 3 (INSL3) hormone-receptor system in the testis. Biology of Reproduction $\mathbf{7 4}$ 945-953. (doi:10.1095/biolreprod.105.048165)

Anand-Ivell R, Wohlgemuth J, Haren MT, Hope PJ, Hatzinikolas G, Wittert G \& Ivell R 2006 $b$ Peripheral INSL3 concentrations decline with age in a large population of Australian men. International Journal of Andrology 29 618-626. (doi:10.1111/j.1365-2605.2006.00714.x)

Anand-Ivell R, Heng K, Hafen B, Setchell B \& Ivell R 2009 Dynamics of INSL3 peptide expression in the rodent testis. Biology of Reproduction $\mathbf{8 1}$ 480-487. (doi:10.1095/biolreprod.109.077552)

Balvers M, Spiess AN, Domagalski R, Hunt N, Kilic E, Mukhopadhyay AK, Hanks E, Charlton HM \& Ivell R 1998 Relaxin-like factor expression as a marker of differentiation in the mouse testis and ovary. Endocrinology 139 2960-2970. (doi:10.1210/en.139.6.2960)

Bay K, Hartung S, Ivell R, Schumacher M, Jürgensen D, Jorgensen N, Holm M, Skakkebaek NE \& Andersson AM 2005 Insulin-like factor 3 serum levels in 135 normal men and 85 men with testicular disorders: relationship to the luteinizing hormone-testosterone axis. Journal of Clinical Endocrinology and Metabolism 90 3410-3418. (doi:10.1210/jc. 2004-2257)

Bogatcheva NV, Truong A, Feng S, Engel W, Adham IM \& Agoulnik AI 2003 GREAT/LGR8 is the only receptor for insulin-like 3 peptide. Molecular Endocrinology 17 2639-2646. (doi:10.1210/me.2003-0096)

Boockfor FR, Fullbright G, Büllesbach EE \& Schwabe C 2001 Relaxin-like factor (RLF) serum concentrations and gubernaculum RLF receptor display in relation to pre- and neonatal development of rats. Reproduction 122 899-906. (doi:10.1530/rep.0.1220899)

Büllesbach EE \& Schwabe C 1999 Specific, high affinity relaxin-like factor receptors. Journal of Biological Chemistry $27422354-22358$. (doi:10.1074/jbc.274.32.22354)

Chamindrani Mendis-Handagama SML 2012 Neonatal-prepubertal hypothyroidism on postnatal testis development. In New Look at Hypothyroidism, pp 209-228. Ed. D Springer. Croatia: InTech.

Chemes H, Cigorraga S, Bergadá C, Schteingart H, Rey R \& Pellizzari E 1992 Isolation of human Leydig cell mesenchymal precursors from patients with the androgen insensitivity syndrome: testosterone production and response to human chorionic gonadotropin stimulation in culture. Biology of Reproduction 46 793-801. (doi:10.1095/biolreprod46.5.793)

Cheng CY \& Mruk DD 2012 The blood-testis barrier and its implications for male contraception. Pharmacological Reviews 64 16-64. (doi:10.1124/pr. 110.002790)

Claus R, Schopper D \& Hoang-Vu C 1985 Contribution of individual compartments of the genital tract to oestrogen and testosterone concentrations in ejaculates of the boar. Acta Endocrinologica 109 281-288.

Domenjoud L, Kremling H, Burfeind P, Maier WM \& Engel W 1991 On the expression of protamine genes in the testis of man and other mammals. Andrologia 23 333-337. (doi:10.1111/j.1439-0272.1991.tb02575.x)

Estienne MJ, Broughton DS \& Barb CR 2000 Serum concentrations of luteinizing hormone, growth hormone, testosterone, estradiol, and

Published by Bioscientifica Ltd. 
leptin in boars treated with $n$-methyl-D,L-aspartate. Journal of Animal Science 78 365-370.

Ewing LL, Zirkin BR, Cochran RC, Kromann N, Peters C \& Ruiz-Bravo N 1979 Testosterone secretion by rat, rabbit, guinea pig, dog, and hamster testes perfused in vitro: correlation with Leydig cell mass. Endocrinology 105 1135-1142. (doi:10.1210/endo-105-5-1135)

Feng S, Bogatcheva NV, Truong A, Korchin B, Bishop CE, Klonisch T, Agoulnik IU \& Agoulnik AI 2007 Developmental expression and gene regulation of insulin-like 3 receptor RXFP2 in mouse male reproductive organs. Biology of Reproduction 77 671-680. (doi:10.1095/biolreprod. 107.060442)

Ferlin A, Garolla A, Rigon F, Caldogno LR, Lenzi A \& Foresta C 2006 Changes in serum insulin-like factor 3 during normal male puberty. Journal of Clinical Endocrinology and Metabolism 91 3426-3431. (doi:10.1210/jc.2006-0821)

FlorCruz SV \& Lapwood KR 1978 A longitudinal study of pubertal development in boars. International Journal of Andrology 1 317-330. (doi:10.1111/j.1365-2605.1978.tb00603.x)

Foresta C, Bettella A, Vinanzi C, Dabrilli P, Meriggiola MC, Garolla A \& Ferlin A 2004 Insulin-like factor 3: a novel circulating hormone of testis origin in humans. Journal of Clinical Endocrinology and Metabolism 89 5952-5958. (doi:10.1210/jc.2004-0575)

Franca LR, Silva VA Jr, Chiarini-Garcia H, Garcia SK \& Debeljuk L 2000 Cell proliferation and hormonal changes during postnatal development of the testis in the pig. Biology of Reproduction 63 1629-1636. (doi:10.1095/ biolreprod63.6.1629)

Gorlov IP, Kamat A, Bogatcheva NV, Jones E, Lamb DJ, Truong A, Bishop CE, McElreavey K \& Agoulnik AI 2002 Mutations of the GREAT gene cause cryptorchidism. Human Molecular Genetics 11 2309-2318. (doi:10.1093/ $\mathrm{hmg} / 11.19 .2309)$

Hanna CB, Yao S, Patta MC, Jensen JT \& Wu X 2010 Expression of insulinlike 3 (INSL3) and differential splicing of its receptor in the ovary of rhesus macaques. Reproductive Biology and Endocrinology 8150. (doi:10.1186/1477-7827-8-150)

Hashino K, Ikawa K, Ito M, Hosoya C, Nishioka T, Makiuchi M \& Matsumoto K 2006 Application of a lanthanide fluorescent chelate label for detection of single-nucleotide mutations with peptide nucleic acid probes. Analytical Biochemistry 355 278-284. (doi:10.1016/j.ab. 2006.06.003)

Hedger MP \& Hettiarachchi S 1994 Measurement of immunoglobulin G levels in adult rat testicular interstitial fluid and serum. Journal of Andrology 15 583-590.

Hess HH, Lees MB \& Derr JE 1978 A linear Lowry-Folin assay for both watersoluble and sodium dodecyl sulfate-solubilized proteins. Analytical Biochemistry 85 295-300. (doi:10.1016/0003-2697(78)90304-4)

Hombach-Klonisch S, Schön J, Kehlen A, Blottner S \& Klonisch T 2004 Seasonal expression of INSL3 and Lgr8/Insl3 receptor transcripts indicates variable differentiation of Leydig cells in the roe deer testis. Biology of Reproduction 71 1079-1087. (doi:10.1095/biolreprod.103. 024752)

Hsu SY, Nakabayashi K, Nishi S, Kumagai J, Kudo M, Sherwood OD \& Hsueh AJ 2002 Activation of orphan receptors by the hormone relaxin. Science 295 671-674. (doi:10.1126/science.1065654)

Huang Z, Rivas B \& Agoulnik AI 2012 Insulin-like 3 signaling is important for testicular descent but dispensable for spermatogenesis and germ cell survival in adult mice. Biology of Reproduction 87 143. (doi:10.1095/ biolreprod.112.103382)

Ivell R \& Anand-Ivell R 2009 Biology of insulin-like factor 3 in human reproduction. Human Reproduction Update 15 463-476. (doi:10.1093/ humupd/dmp011)

Ivell R \& Bathgate RA 2002 Reproductive biology of the relaxin-like factor (INSL3). Biology of Reproduction 67 699-705. (doi:10.1095/biolreprod. 102.005199)

Jegou B \& Le Gac-Jegou F 1978 Androgen-binding protein in the seminal plasma of some mammalian species. Journal of Endocrinology $\mathbf{7 7}$ 267-268. (doi:10.1677/joe.0.0770267)
Jin W, Arai KY, Herath CB, Kondo M, Ishi H, Tanioka Y, Watanabe G, Groome NP \& Taya K 2001 Inhibins in the male Gottingen miniature pig: Leydig cells are the predominant source of inhibin B. Journal of Andrology 22 953-960.

Kato S, Siqin, Minagawa I, Aoshima T, Sagata D, Konishi H, Yogo K, Kawarasaki T, Sasada H, Tomogane $\mathrm{H}$ et al. 2010 Evidence for expression of relaxin hormone-receptor system in the boar testis. Journal of Endocrinology 207 135-149. (doi:10.1677/JOE-10-0149)

Kawamura K, Kumagai J, Sudo S, Chun SY, Pisarska M, Morita H, Toppari J, Fu P, Wade JD, Bathgate RA et al. 2004 Paracrine regulation of mammalian oocyte maturation and male germ cell survival. PNAS 101 7323-7328. (doi:10.1073/pnas.0307061101)

Kohsaka T, Takahara H, Sugawara K \& Tagami S 1993 Endogenous heterogeneity of relaxin and sequence of the major form in pregnant saw ovaries. Biological Chemistry Hoppe-Seyler 374 203-210. (doi:10.1515/bchm3.1993.374.1-6.203)

Kohsaka T, Sasada H, Takahara H, Sato E, Bamba K \& Sherwood OD 2001 The presence of specific binding sites on boar spermatozoa for porcine relaxin and its action on their motility characteristics. Journal of Reproduction and Development 47 197-204. (doi:10.1262/jrd.47.197)

Kumagai J, Hsu SY, Matsumi H, Roh JS, Fu P, Wade JD, Bathgate RA \& Hsueh AJ 2002 INSL3/Leydig, insulin-like peptide activates the LGR8 receptor important in testis descent. Journal of Biological Chemistry $\mathbf{2 7 7}$ 31283-31286. (doi:10.1074/jbc.C200398200)

Lee S, Kim GD, Park WK, Cho H, Byung HL, Yoo SE \& Kong JY 2006 Development of a time-resolved fluorometric assay for the high throughput screening of melanin concentrating hormone receptor antagonists. Journal of Pharmacological and Toxicological Methods $\mathbf{5 3}$ 242-247. (doi:10.1016/j.vascn.2005.09.001)

Lövgren T, Hemmilä I, Pettersson K \& Halonen P 1985 Time-resolved fluorometry in immunoassay. In Alternative Immunoassays, pp 203-217. Ed. WP Collins. Chichester: John Wiley \& Sons.

Lui WY \& Lee WM 2009 Molecular mechanisms by which hormones and cytokines regulate cell junction dynamics in the testis. Journal of Molecular Endocrinology 43 43-51. (doi:10.1677/JME-08-0174)

Lunstra DD, Ford JJ, Christenson RK \& Allrich RD 1986 Changes in Leydig cell ultrastructure and function during pubertal development in the boar. Biology of Reproduction 34 145-158. (doi:10.1095/ biolreprod34.1.145)

Minagawa I, Fukuda M, Ishige H, Kohriki H, Shibata M, Park EY, Kawarasaki T \& Kohsaka T 2012 Relaxin-like factor (RLF)/insulin-like peptide 3 (INSL3) is secreted from testicular Leydig cells as a monomeric protein comprising three domains B-C-A with full biological activity in boars. Biochemical Journal 441 265-273. (doi:10.1042/BJ20111107)

Mruk DD \& Cheng CY 2010 Tight junctions in the testis: new perspectives. Philosophical Transactions of the Royal Society of London. Series B, Biological Sciences 365 1621-1635. (doi:10.1098/rstb.2010.0010)

Muda M, He C, Martini PG, Ferraro T, Layfield S, Taylor D, Chevrier C, Schweickhardt R, Kelton C, Ryan PL et al. 2005 Splice variants of the relaxin and INSL3 receptors reveal unanticipated molecular complexity. Molecular Human Reproduction 11 591-600. (doi:10.1093/ molehr/gah205)

Nef S \& Parada LF 1999 Cryptorchidism in mice mutant for Insl3. Nature Genetics 22 295-299. (doi:10.1038/10364)

Noguchi M, Yoshioka K, Itoh S, Suzuki C, Arai S, Wada Y, Hasegawa Y \& Kaneko H 2010 Peripheral concentrations of inhibin A, ovarian steroids, and gonadotropins associated with follicular development throughout the estrous cycle of the sow. Reproduction 139 153-161. (doi:10.1530/REP-09-0018)

Ogine T, Kohsaka T \& Taya K 1999 Time-resolved fluoroimmunoassay (TR-FIA) of porcine relaxin. Experimental and Clinical Endocrinology \& Diabetes 107 276-280. (doi:10.1055/s-0029-1212112)

Peyrat JP, Meusy-Dessolle N \& Garnier J 1981 Changes in Leydig cells and luteinizing hormone receptors in porcine testis during postnatal development. Endocrinology 108 625-631. (doi:10.1210/endo-1082-625) 
Raeside JI \& Renaud RL 1983 Estrogen and androgen production by purified Leydig cells of mature boars. Biology of Reproduction 28 727-733. (doi:10.1095/biolreprod28.3.727)

Sadeghian H, Anand-Ivell R, Balvers M, Relan V \& Ivell R 2005 Constitutive regulation of the Insl3 gene in rat Leydig cells. Molecular and Cellular Endocrinology 241 10-20. (doi:10.1016/j.mce.2005.03.017)

Sasaki Y, Kohsaka T, Kawarasaki T, Sasada H, Ogine T, Bamba K \& Takahara H 2001 Immunoreactive relaxin in seminal plasma of fertile boars and its correlation with sperm motility characteristics determined by computer-assisted digital image analysis. International Journal of Andrology 24 24-30. (doi:10.1046/j.1365-2605.2001.00259.x)

Schwarzenberger F, Toole GS, Christie HL \& Raeside JI 1993 Plasma levels of several androgens and estrogens from birth to puberty in male domestic pigs. Acta Endocrinologica 128 173-177.

Scott DJ, Layfield S, Yan Y, Sudo S, Hsueh AJ, Tregear GW \& Bathgate RA 2006 Characterization of novel splice variants of LGR7 and LGR8 reveals that receptor signaling is mediated by their unique low density lipoprotein class A modules. Journal of Biological Chemistry $\mathbf{2 8 1}$ 34942-34954. (doi:10.1074/jbc.M602728200)
Siqin, Nakai M, Hagi T, Kato S, Pitia AM, Kotani M, Odanaka Y, Sugawara Y, Hamano K, Yogo K et al. 2010 Partial cDNA sequence of a relaxin-like factor (RLF) receptor, LGR8 and possible existence of the RLF ligandreceptor system in goat testes. Animal Science Journal 81 681-686. (doi:10.1111/j.1740-0929.2010.00801.x)

Wikström AM, Bay K, Hero M, Andersson AM \& Dunkel L 2006 Serum insulin-like factor 3 levels during puberty in healthy boys and boys with Klinefelter syndrome. Journal of Clinical Endocrinology and Metabolism 91 4705-4708. (doi:10.1210/jc.2006-0669)

Yamaguchi Y, Hashino K, Ito M, Ikawa K, Nishioka T \& Matsumoto K 2009 Sodium dodecyl sulfate polyacrylamide slab gel electrophoresis and hydroxyethyl cellurose gel capillary electrophoresis of luminescent lanthanide chelate-labeled proteins with time-resolved detection. Analytical Sciences 25 327-332. (doi:10.2116/analsci.25.327)

Zimmermann S, Steding G, Emmen JM, Brinkmann AO, Nayernia K, Holstein AF, Engel W \& Adham IM 1999 Targeted disruption of the Insl3 gene causes bilateral cryptorchidism. Molecular Endocrinology 13 681-691. (doi:10.1210/me.13.5.681)

Received in final form 16 December 2013 Accepted 19 December 2013
(C) 2014 Society for Endocrinology Printed in Great Britain
Published by Bioscientifica Ltd. 